\title{
Protests Decentralised: How technology enabled civil disobedience by Hong Kong anti-extradition bill protesters
}

\author{
8th Asian Privacy Scholars Network Conference Paper 2020 \\ Janis Wong \\ School of Computer Science \\ University of St Andrews, Scotland
}

\begin{abstract}
The proposal of the Fugitive Offenders and Mutual Legal Assistance in Criminal Matters Legislation (Amendment) Bill 2019 (2019年逃犯及刑事事宜相互法律協助法例(修訂)條例草 案) (FOMLA) by the Hong Kong government, aimed at closing the gap for extradition to Taiwan, Macau, and Mainland China, sparked dozens of city-wide protests as demonstrators feared it would erode Hong Kong's legal system, including rights to privacy and data protection, under the Hong Kong Basic Law (HKBL).

Facilitated by technology, the leaderless, decentralised demonstrations furthered the anti-extradition bill protests by establishing legitimacy, participation, trust, and privacy between citizens under the 'One Country, Two Systems' framework. Based on these themes, this paper assesses how Hong Kong protesters found novel uses of technology such as Telegram, Apple Airdrop, cash and untraceable transactions, LIHKG Forum, and protest livestreams to self-organise, demonstrate their support for the movement, and maintain its momentum. The protesters' use of technology also shaped Twitter, Facebook, and Youtube policies, removing bot accounts and state-sponsored disinformation from their platforms.

Learning from the city's past protests, arrests, and convictions, this paper illustrates how Hong Kong protesters transformed their use of technology as a means to protect their personal identities, preserve their rights enshrined under the HKBL, and strive for democratic freedoms.
\end{abstract}

\section{Introduction}

Technology has become an important part of communication, freedom of expression, and how individuals and communities express themselves both online and offline. As one of the most connected cities in the world, Hong Kong is no exception. The city has one of the fastest internet speeds globally [5] and is home to the Nobel Prize in Physics recipient Sir Charles Kuen Kao (高錕) for his work on fibre optic communications [64], the most mobile connections per capita [15], and is ranked fourth in technological infrastructure innovation [18]. In Hong Kong's data-driven society [57], it is therefore no surprise that technology played an important role in enabling civil disobedience for the protest against the Fugitive Offenders and $\mathrm{Mu}-$ tual Legal Assistance in Criminal Matters Legislation (Amendment) Bill 2019 (2019年逃犯及刑事事宜相互法律協助法
例(修訂)條例草案) (FOMLA). While the use of technology in protest movements is not new and is widely written by scholars [75] [76] [81], Hong Kong anti-extradition law amendment bill (反送中) (anti-ELAB) protesters learnt from their civil disobedience pasts and transformed how such new and old technologies can further protester aims.

This paper aims to examine how Hong Kong protesters used technology to enable civil disobedience in preserving their fundamental rights and freedoms, thus safeguarding their identities. In Section 2, I will outline Hong Kong's legal framework, the rights granted to the people under the law, and the legislative process. I will also introduce FOMLA and how it fits into this legal and political structure, leading up to the start of the anti-ELAB protests. While this section aims to provide background information for audiences unfamiliar with the Hong Kong legal system, it does not comprehensively cover all events that take place during the protests. Further, protests in Hong Kong are ongoing at the time of writing and the use cases identified may be subject to change. In Section 3, I introduce the demands of the Hong Kong protesters beyond the withdraw of the FOMLA bill, outlining how these demands tie in closely with preserving the Hong Kong identity through protecting the rights of the Hong Kong people. Exploring technology through the themes of participation, legitimacy, trust, and protection in Section 4, I explore how demonstrators changed their use of technology over time to enable and sustain their civil disobedience. In Section 5, I briefly discuss what Hong Kong's future may hold with regards to how protesters, the Government, and China may react to how technology has enabled the anti-ELAB protests. Finally, I conclude that while technology did not cause or determine the protests, it played a crucial role in shaping the anti-ELAB movement in Hong Kong and changed the international discourse on civil disobedience.

\section{The Hong Kong Legal System and Anti-Extradition Bill}

Governed by the Hong Kong Basic Law (HKBL) [73], the Hong Kong Special Administrative Region of the People's Republic of China represents an oddity of colonial legislative and political history. After 156 years of British rule since the end of the First Opium War in 1842 [6], the territory of Hong Kong was handed over to China in 1997. To ease the transition, the new legal framework 'One Country, Two Systems' was implemented 
in order for Hong Kong to maintains its legal, economic, and administrative systems while demonstrating Britain's commitment to the 'One-China' policy. The head of the Hong Kong Government, the Chief Executive, is appointed by China's Central People's Government (Article 15). The Legislative Council is the legislature of Hong Kong (Article 67). Under the existing political framework, Hong Kong citizens are only able to directly elect 35 out of 70 Legislative Council geographical constituency Members [33] despite Article 68 outlining that 'the ultimate aim is the election of all the members of the Legislative Council by universal suffrage'. Under the HKBL, Hong Kong can 'exercise a high degree of autonomy and enjoy executive, legislative and independent judicial power, including that of final adjudication, in accordance with the provisions of this Law' (Article 2). The existing rights of Hong Kong people are also protected by the HKBL, including 'the right to vote and the right to stand for election' (Article 26), 'freedom of speech, of the press and of publication; freedom of association, of assembly, of procession and of demonstration; and the right and freedom to form and join trade unions, and to strike' (Article 27), 'freedom and privacy of communication' (Article 30), and 'freedom of conscience' (Article 32). The 'One Country, Two Systems' framework governing Hong Kong includes that the 'capitalist system and way of life shall remain unchanged for 50 years' (Article 5).

In February 2019, the Hong Kong Government first proposed FOMLA to close the extradition gap following the murder of Poon Hiu Wing (潘曉穎) by her boyfriend Chan Tong Kai (陳 同佳) in Taiwan in 2018, where the two Hong Kong residents were visiting at the time. As Hong Kong does not have extradition treaties with Taiwan, the Hong Kong government proposed amendments to the Fugitive Offenders Ordinance (Cap. 503) [70] and Mutual Legal Assistance in Criminal Matters Ordinance (Cap. 525) [69], to establish a mechanism for case-bycase transfers of fugitives to any jurisdiction with which the city lacks a formal extradition treaty as approved by the Chief Executive and local courts. These jurisdictions includes Taiwan, Macau, and Mainland China. The FOMLA bill, as a result of the possibility to be extradited to Mainland China, became known as ELAB and thus the anti-ELAB protests.

\subsection{The Anti-Extradition Bill Protests}

The Hong Kong Government took significant measures in an attempt to fast-track FOMLA through the legislative process, leading up to the anti-ELAB demonstrations. In Hong Kong, in order for bills to pass in the Legislative Council, the Chief Executive or Legislative Council members must publish the bill in the Gazette. The bill must then go through three readings in the Legislative Council before it is passed. This process is outline in HKBL Chapter IV and presented in Figure 1. Presenting the bill to the Legislative Council [14], the bill was published in the March 2019 Gazette and was scheduled for its First Reading in April 3. However, even with assurances from the Government that political cases will not be prosecuted in such way, under the backdrop of ongoing attempts to push the National Security (Legislative Provisions) Bill 2003 forward [74], the 'missing' Hong Kong booksellers cases [55], and the imprisonment of Chinese human rights lawyers [79], individuals and groups publicly expressed their concerns on FOMLA: The legal sector warned

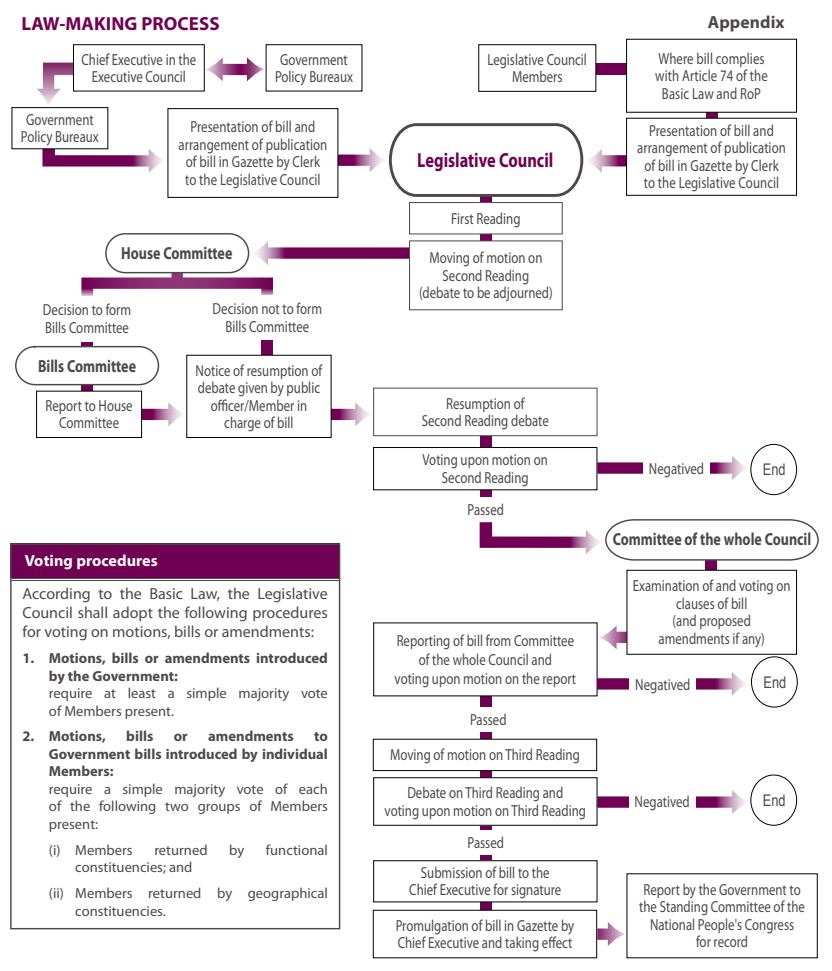

Figure 1: The law-making process in the Legislative Council [32].

that the bill would undermine the international community's confidence with Hong Kong's judicial system [83]; the President of the American Chamber of Commerce said that passing the bill would risk 'shooting Hong Kong in the foot' [88]; the Hong Kong Journalists Association released a statement opposing the bill, stating that it "will not only threaten the safety of journalists but also have a chilling effect on the freedom of expression in Hong Kong' [4]. Taiwan also expressed that it would not seek to extradite the suspect under FOMLA and requests that the case be dealt with differently by the Hong Kong authorities [48]. Despite these concerns, the Hong Kong Government decided to call on the House Committee chair (a pro-Government lawmaker), to allow the FOMLA to bypass the First Reading and begin its Second Reading on June 12, citing that this could be done following the Legislative Council Rules of Procedure [8].

In the lead up to the June 12 Legislative Council meeting, the Civil Human Rights Front, a coalition of pro-democracy group that focuses on Hong Kong politics, organised the first anti-ELAB protest on June 9. The protest saw what the organisers estimated to be around 1.03 million people, with the police figure at 240,000 [19]. The turnout was the highest recorded, by organiser and police figures, since the handover in 1997 (only to be surpassed by the later June 16 protest). On the same evening, several protesters were arrested [45] and the Chief Executive, Carrie Lam Cheng Yuet Ngor (林鄭月娥), and the Hong Kong Government issued a statement stating that the Second Reading would proceed as scheduled on June 12 [34]. With the public mobilised given the large turnout, protesters called for a strike and to surround the Legislative Council building on June 12, successfully delaying the Second Reading [60]. The Hong Kong Police Force (HKPF) fired rubber bullets, bean bag rounds, and 
tear gas to disperse protesters. It was also the first day the HKPF described the anti-ELAB protests as 'riots' [23]. The characterisation of the protests of riots is particularly sensitive under Hong Kong's legal framework [72] as the term is broadly defined from the colonial era and carries up to 10 years imprisonment [38]. The Second Reading of FOMLA was suspended by the Chief Executive on June 15 but without a formal withdrawal of the bill [87]. As a result, anti-ELAB demonstrators once again took to the streets on June 16 . The protest saw what organisers estimated to be around 2 million people, over a quarter of the city's population, with the police figure at 338,000 at its peak [59]. Despite the large number of protesters, the Chief Executive refused to withdraw the bill or meet protester demands. The FOMLA bill was officially withdrawn from the Gazette on October 23 [16]. Although the bill had been withdrawn, protests continue into its sixth month at the time of writing, as demonstrators saw the bill's withdraw as "too little, too late" [17].

\section{Beyond the Anti-Extradition Bill}

As the protests gained momentum, so did the protesters' use of technology to harness its power to grow the movement. Its first use was to circulate the new demands from anti-ELAB protesters.

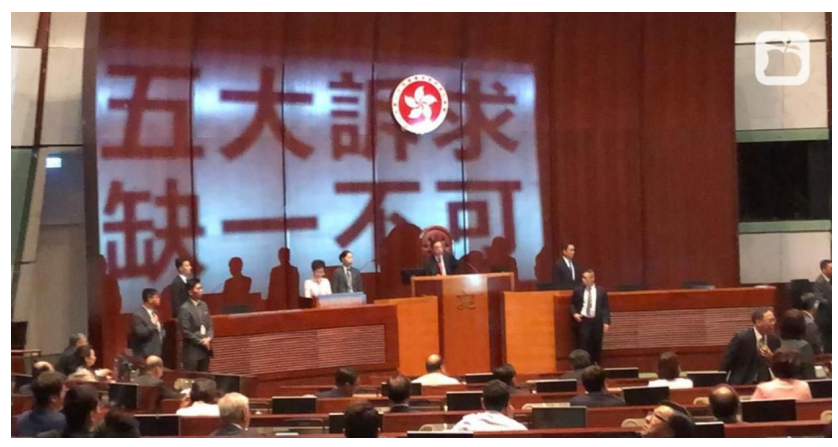

Figure 2: The anti-ELAB protest slogan 五大訴求, 缺一不可 (Five Demands, Not One Less) projected in the Legislative Council by prodemocracy legislators, where the Chief Executive Carrie Lam (in white) is addressing the chamber. Photo by Apple Daily Media.

Following the June 16 protest, the refusal for the government to withdraw FOMLA, the use of the term 'riot' to characterise the anti-ELAB protests, and the increased use of force by the HKPF, led the protesters to establish their core five demands, representing the fears of eroding freedoms that are supposed to be protected under the HKBL. These demands are expressed by the chant commonly heard at anti-ELAB protests, 'Five Demands, Not One Less' (五大訴求, 缺一不可). These demands are:

1. Full withdrawal of the extradition bill;

2. A commission of inquiry into alleged police brutality;

3. Retracting the classification of protesters as 'rioters';

4. Amnesty for arrested protesters; and

5. Dual universal suffrage, meaning for both the Legislative Council and the Chief Executive [85].

\subsection{Technology as part of the Hong Kong Identity}

While the anti-ELAB protester demands are not directly related to privacy and data protection, they relate to protesters' identity as Hong Kong people and their refusal to have their rights taken away [20]. Despite the relatively free online environment, Hong Kong people know how technologies can be used against them. In recent years, the Hong Kong Government has increasingly introduced surveillance mechanisms into people's daily lives. For example, new compulsory identity cards began to roll out in 2018 with built-in radio frequency identification (RFID) technology and higher resolution photographs to support facial recognition [51]. The number of CCTV cameras in the city is also high, with a conservative estimate of 50,000 units in the public sector alone in 2014 [44]. In 2010, the HKPF traced data from the Hong Kong Octopus transport card to catch and convict a suspect in an acid-attack case [37]. In Hong Kong's digitally well-connected society, unencumbered by the Great Firewall of China [28] in a geopolitical 'no-man's land, but with a vibrant media protest culture, not to mention largely unfiltered Internet' [65], the use of digital technologies have shaped the lives of Hong Kong people, separating them from their Mainland Chinese counterparts, socially, culturally, and importantly, politically.

\section{Anti-Extradition Bill Protests and Technology}

After establishing the legal and socio-political foundations that have enabled the anti-ELAB protests, this section thematically explores how technology enabled the ongoing civil disobedience. Assessing how the use of technology changes over time, I explore how demonstrators learnt from their protest pasts and carefully used technology to further the anti-ELAB movement.

\subsection{Technology for Participation}

Technology as a means for communication plays an important role for protest participation, particularly where protesters need to respond quickly to changes in the political environment. Networked protests can be described as "adhocracy", where tasks are accomplished ad hoc by whoever is available to do them. This has been seen in protest movements such as the anti-Mubarak events in Egypt leading up to Arab Spring [76]. However, what differentiates Hong Kong's anti-ELAB demonstrations is that while digital organisation often places the 'how' in protest organisation later, Hong Kong protesters started with the 'how' in considering the technological infrastructure that can both protect their identities while supporting the movement. Regardless of location, time, or whether people are active or passive participants in civil disobedience, technology unlocks new sources of information.

For active protesters, online tools can help mask their identity while allowing them to meaningfully engage with discussions on protest tactics to be implemented offline. For example, the LIHKG Forum [24], a Reddit-like platform that is available on desktop and mobile, allows people registered with a Hong Kong ISP or those with an academic or institutional email address to sign up and anonymously post, upload, vote, and chat. Votes also commonly take place after big events as a means for protesters to collectively decide the next cause of action within the decentralised and leaderless protests. Those not registered 
can only view LIHKG posts. All LIHKG posts are written in colloquial traditional Chinese and Cantonese, the language spoken in Hong Kong. This lowers the barrier of entry for Hong Kong people to participate in conversations on the protests while simultaneously limiting those who cannot understand Cantonese from engagement. This infrastructure provides what Tufekci describes as "network internalities", the benefits and collective capabilities obtained from the constant work of negotiation and interaction required to maintain the networks as functioning and durable social and political structures [76]. While in leaderless protests, individuals are free to do whatever they please, the "network internalities" enabled by having a bespoke platform dedicated to the anti-ELAB protests allow protesters to meaningfully engage and decide on future action through their networked community.

Existing technological functionalities can also be re-purposed by those who are active protesters to widen their reach, raising awareness of both future protest events and of incidences of violence towards protesters to audiences who otherwise would not know about what is happening. One such method is through Apple AirDrop, a file sharing feature available on Apple devices that works within a distance of 9 metres. As the iPhone, Apple's smartphone, has become more mainstream, AirDrop has been a more common means of communication. Teenagers now use AirDrop to frequently share memes with each other [49]. Hong Kong protesters have used Apple's functionality to target tourists travelling to Hong Kong from Mainland China [35]. The iPhone market is large in Mainland China, where it has the highest revenue across all Chinese smartphone brands, consistently ranking in the top five best-selling brands, as is the country's top foreign smartphone company in sales [61]. As China's Great Firewall prevents those using Chinese applications from accessing information about the anti-ELAB protests, Hong Kong demonstrators have used AirDrop to bypass such restrictions. Posts written in simplified Chinese (as opposed to traditional Chinese) are shared to all devices that have AirDrop turned on. Although the exposure to more information about the protests have mixed results with Chinese tourists [84], using commonplace technologies as part of civil disobedience can help mobilise more people and encourage participation.

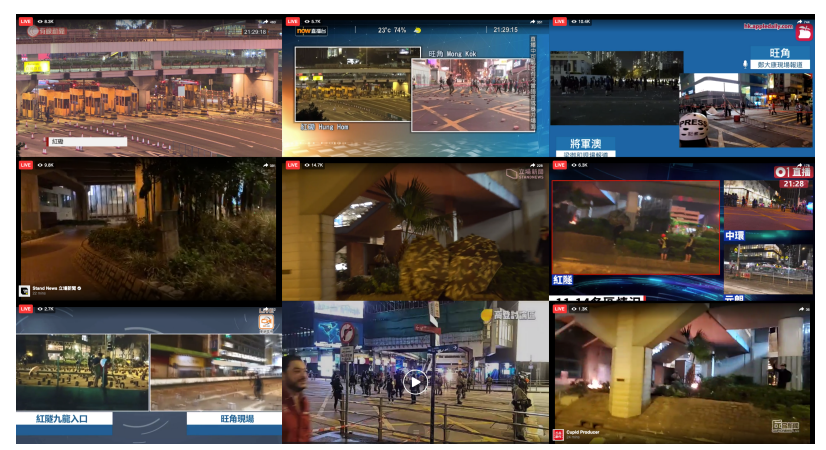

Figure 3: Hosted on Github, this tool simultaneously broadcasts protest livestreams on a single screen, where the number of live videos playing at the same time can go up to 16 [52].

With the aid of innovation in multimedia technology and high levels of internet connectivity across the city, the anti-
ELAB protests are also the most livestreamed protest movement in the world [36]. Almost all livestreams have been done through Facebook Live, with the exception of individuals streaming on Instagram's IGTV when waiting for journalists to arrive on scene. It has become the most trusted source of information about the protests by those who are not physically there, scoring 8.12 out of 10 , above the 6.85 for traditional media and 6.01 for social media, for its importance in debunking misinformation and disinformation [46]. Independent projects have also sprung up to create collages of livestreams by different media companies (Figure 3 ). Used as a means of holding those in power to account, the livestreaming of anti-ELAB has resulted in more transparency with regards to how acts of civil disobedience have evolved over events, how protester arrests have been made, and ensure that those arrested are able to share their name and ID number with social workers and lawyers not on site who can follow up on cases. To counter the daily HKPF press conferences where the Police are criticised for repeating the same talking points and refusing to answer reporters' questions, citizens' press conferences were organised by members of the public to represent the people's unheard voice [53]. Mobilising citizens and enabling passive civil disobedience, the livestreaming of anti-ELAB protests have not only made it more difficult for Hong Kong people to not participate in the movement, but also encouraged those abroad to experience anti-ELAB demonstrations for themselves.

\subsection{Technology for Legitimacy}

Bringing an offline protest online (and vice versa) and legitimising digital civil disobedience can be difficult as people are increasing inundated with information. Historical means of transmitting the power of protests online include traditional media documentation of the protests happening on the ground. However, anti-ELAB protesters have taken to technology to publicise, lead the conversation, and legitimise the movement domestically and internationally. While traditional forms of social media also encourage participation, the roles of platforms such as Facebook, Twitter, and Instagram, help to legitimise the anti-ELAB protests. This is particularly the case for international coverage of local news and events, where the use of hashtags such as \#HongKongProtests and \#anti-ELAB make it easier to follow and understand that is happening on the ground. \#StandWithHK and \#FollowBackHongKong were trending in Hong Kong after Twitter saw a new wave of anti-ELAB protesters create new accounts in an attempt to share protest news more widely [27]. After persuasion from users, LIHKG also set up Facebook, Twitter, and Instagram accounts, translating some posts and videos from traditional Chinese to English. Academics such as Leung Kai Chi (梁啓 智) [11], a lecturer at the Chinese University of Hong Kong, have created Twitter profiles to specifically disseminate public opinion research findings on the anti-ELAB protests. Memes and art have also played an important role in spreading the protests online, creating memorable images beyond the postit Lennon Walls [12] plastered across the city during the early days of the movement. Anonymous Twitter accounts such as @uwu_uwu_mo have been dedicated to sharing the 'Art of Resistance' [77]. An example of such artwork is illustrated in Figure 4 . 


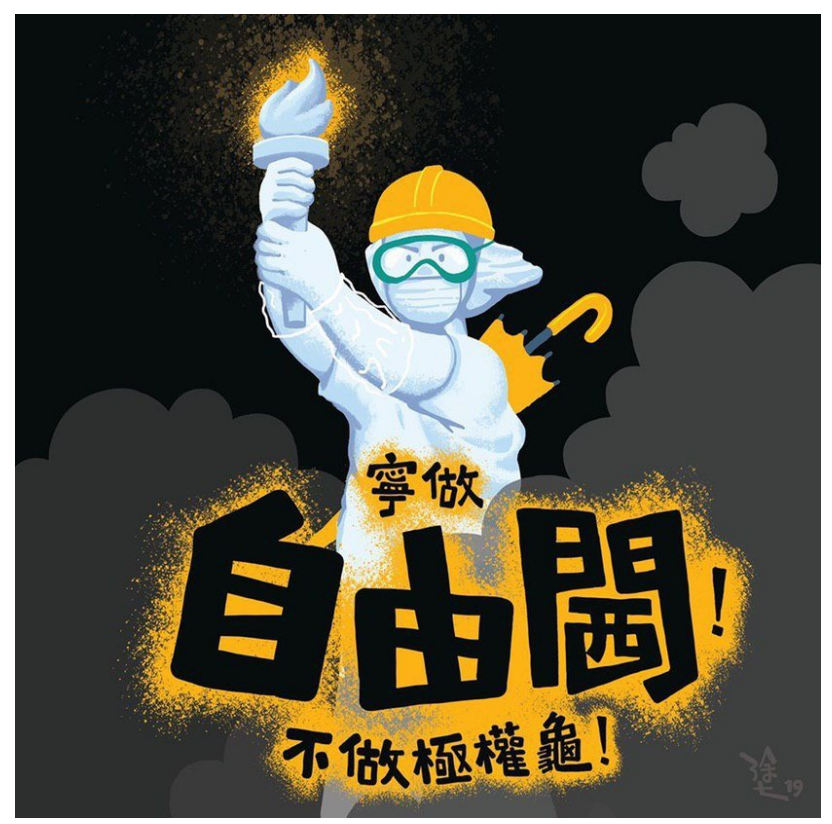

Figure 4: Protest artwork created by 阿塗 (AhTo_comic) incorporating many elements of the anti-ELAB movement, including Lady Liberty Hong Kong, a hard hat, goggles, a face mask, tear gas, 'freedom hi', and the colour yellow.

Online crowdfunding campaigns have also been an alternative means to demonstrate support for the anti-ELAB movement from those who may not be able to protest on the streets as well as to new audiences. Successful crowdfunding campaigns saw the creation of the new 'Lady Liberty Hong Kong' statue that reached its goal for raising HK\$200,000 (US\$25,543) within six hours [41], a global advertising campaign to raise awareness of the protests on newspapers around the world reached its goal of HK $\$ 7,800,000$ (US $\$ 1,000,000)$ in one hour [10], and a call for funding for Edward Leung's (梁 天琦; the activist who was sentenced to six years in jail after being convicted of rioting and the creator of what has become the anti-ELAB slogan 光復香港, 時代革命 'Liberate Hong Kong, the revolution of our times') sentence appeal of HK\$350,000 (US\$44,872) was raised in 15 minutes [9]. All of these campaigns were advertised on LIHKG and other social media platforms. The speed of which these crowdfunding campaigns reached their goals not only demonstrates the widespread support for the protest movement but also how the technological infrastructure illustrated in Section 4.1 creates an environment that can foster different means of legitimising the movement offline.

Hong Kong protesters' use of technology has also had an impact on technology and influenced disinformation policies of technology platforms. On August 19, Twitter revealed in a blog post that it disclosed 936 accounts originating from the People's Republic of China that were part of a wider network of approximately 2,000 accounts which form part of a state-backed operation that was "deliberately and specifically attempting to sow political discord in Hong Kong, including undermining the legitimacy and political positions of the protest movement on the ground" [62]. Based on this report, Facebook removed seven
Pages, three Groups and five Facebook accounts "involved in coordinated inauthentic behavior as part of a small network that originated in China and focused on Hong Kong" [26]. Youtube disabled 210 channels that "behaved in a coordinated manner while uploading videos related to the ongoing protests in Hong Kong" [39]. Further, the Hong Kong protests were also brought to the gaming and e-sports community. After winning the Asia-Pacific Grandmasters Competition, pro-Hearthstone player Blitzchung was stripped of his prize money and suspended for a year after he chanted the slogan 光復香港, 時 代革命 (Liberate Hong Kong, the revolution of our times) in a post-match interview [22]. With more than two million mobile gamers in Hong Kong, where 48\% play everyday compared to the global average of $39 \%$ [86], it becomes less surprising that anti-ELAB was brought to the console. By making use of existing online communities to publicise and legitimise the antiELAB protests, Hong Kong protesters frustrated China's Great Firewall and chanced upon an increasingly sensitive digital information landscape, resulting in more attention drawn to the city's civil disobedience movement.

\subsection{Mitigating Mistrust in Technology}

As political tensions run high both online and offline following past experiences of the 2014 Umbrella Movement, Hong Kong people have become both more reliant and more weary of how technology can help and also hinder civil disobedience. Using technology, protesters have enabled and furthered the breadth and depth of the protests. Knowledge of these tools have been a source of power for the protesters, where this power includes understanding how technology can be used and abused to the detriment of protesters.

Since the Umbrella Movement in 2014, local non-profit organisations such as Keyboard Frontline have published handbooks and education materials to teach protesters how to stay safe online [25]. To this day, a lack of trust in technology persists, especially where past cases such as those mentioned in Section 3 have resulted in arrests. To communicate protest activities, protesters have turned to Telegram for its encrypted chats to prevent messages from being spied on by the Government. Protestors also use Telegram to arrange safe transportation for people to leave demonstration sites if no public transport is available [78]. On June 12, the day of the scheduled Second Reading for FOMLA, Pavel Durow, the founder of the end-to-end encrypted messaging service Telegram (see Section 4.3), stated that the Chinese Government performed a distributed denial-of-service (DDoS) attack as a means to disrupt the protests in Hong Kong when demonstrators were surrounding the Legislative Council building [21]. Telegram later changed its policy in direct response to the Hong Kong protests and the protesters' privacy concerns, allowing users to cloak their telephone numbers to safeguard them against monitoring by authorities [63]. Burner phones with disposable SIM cards are also used by protesters in case their personal data is leaked. After the Executive Councillor said that the government "would not rule out a ban on the Internet", on the same day, the NordVPN app became the most downloaded app in Hong Kong [40]. The anti-ELAB symbols of face masks, gas masks, and umbrellas are used as shields against both the police and prying cameras [3]. When leaving protest sites, protesters 
opt for cash tickets instead of using the Octopus card for fear of being tracked [50]. Anti-ELAB protesters also took down new 'smart' lampposts, where their full technological capabilities have not been disclosed, installed by the Government during a protest against surveillance and increasing prevalence of facial recognition technologies [54]. While those who participate in civil disobedience use technology to better understand and actively engage with the protests, the protesters remain cautious with the belief that while technology could be used for good, mistrust in technology go hand-in-hand with mistrust in the Government.

\subsection{Technology for Protection}

Technology, and information on how to use technology, is also important to ensure that protesters and their identities can be protected. However, the Government has also taken measures to limit the safety net technology provides to anti-ELAB protesters.

Using technology for protection can only work if such uses of technology are allowed. For both active and passive protesters, one form of using technology for protection is by knowing where the protests are happening, where demonstrators have dispersed to after the protests, and where the police are and plan to go. HKmap.live (全港抗爭即時地圖), a Hong Kong protest live map was created on August 5 to provide information for Hong Kong residents on the whereabouts of anti-ELAB related events (Figure 5). HKmap.live is available as a website, mobile application, and on Telegram. The information provided by HKmap.live is crowdsourced and is an important resource for protesters as well as for those who want to avoid the protests. Importantly, HKmap.live also provides the rough location of where the police are and the direction that they are headed. Despite the necessity for Hong Kong residents to know which areas may be tear gassed, pepper sprayed, or demonstrate other signs of danger, the mobile application was banned from the Apple App Store on October 3 [30], allowed on the same day, then pulled off of the App Store on October 10. In an internal email statement from Tim Cook explaining why HKmap.live was pulled, he stated that "the app was being used maliciously to target individual officers for violence and to victimize individuals and property where no police are present" [2]. This is disputed by both the application creator [31] and by Pinboard [58] citing that only broad locations are identified with significant lag, no individuals can be identified on the application, and that the app does not violate Hong Kong laws as claimed. In addition to HKmap.live, the application for the Chinese version of Quartz, the news organisation, was also removed from the Apple App Store over its coverage of the Hong Kong protests after complaints from the Chinese Government [68]. The removal of both applications demonstrate successful attempts by the Hong Kong and Chinese authorities to limit the scope of protection offered by technology and technology companies, outlining the fragile relationships protesters may have with companies that serve Mainland China under geopolitical pressure.

The Government and authorities have also used the law against anti-ELAB protesters. Interim injunctions have been granted to bar the public from inspecting the voters registry [82] and to prevent the disclosure of police officers' and their extended families' personal data [29] which was later clarified and

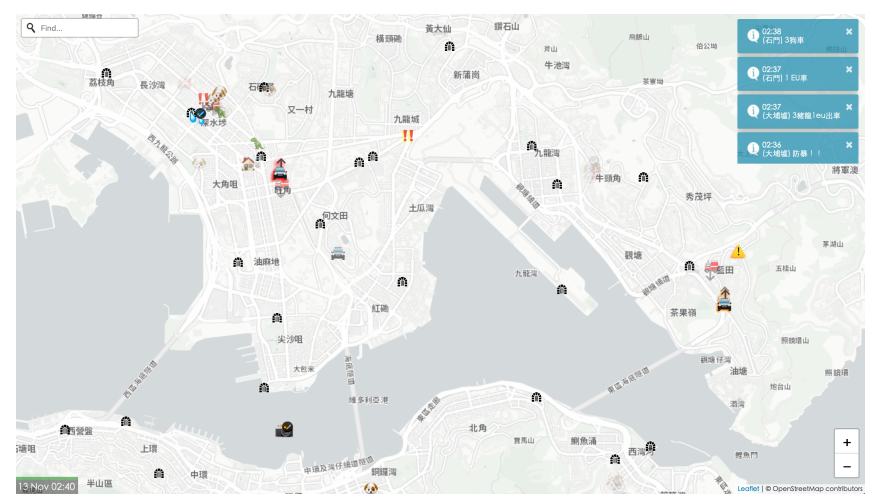

Figure 5: A screenshot taken from HKmap.live, illustrating information such as where the police are, where police vehicles are and where they are bound, and the location of water cannons, tear gas, pepper spray and where other clashes may be. The top-right corner provides real-time updates when they are available.

narrowed [42]. The Hong Kong Journalists Association later sought and was successfully granted an exemption for journalists from revealing personal information about police officers [43]. The Secretary of Justice applied and was granted an interim injunction that involved asking the court to restrain anyone from "disseminating, circulating, publishing, or re-publishing" any information or material that "promotes, encourages or incites" the use or threat of violence, intended or likely to cause bodily injury or property damage, directly listing Telegram and LIHKG as examples [7]. The Internet Society and the Internet Society Hong Kong Chapter has expressed its concerns for its negative impact on internet infrastructure as it puts Hong Kong society at risk [67] and is currently crowdfunding to challenge the Government's injunction [66]. Most controversially, in an attempt to erode anti-ELAB protesters' anonymity offline and online, the Chief Executive invoked the colonial era Emergency Regulations Ordinance, enacted in 1922 and last used in 1967, to put into force the Prohibition on Face Covering Regulation, broadly banning face masks permanently by only allowing them to be worn under limited circumstances [71]. The Human Rights Watch has argued that the ban violates freedom of assembly rights [80]. Using technology as a shield, anti-ELAB protesters have been able to protect themselves with and also against technology. However, the Government has taken substantial measures to decrease protesters' ability to self-organise and use the internet to further enable civil disobedience. Even so, as it is unclear how some of these injunctions could be enforced, protesters continue to use these technologies, and wear face masks, as part of the anti-ELAB protests.

\section{Future of Civil Disobedience and Online Discourse}

With the protests entering its sixth month and is ongoing as of writing, technology continues to play an important, although increasingly small, role in pushing the momentum of the antiELAB movement forward. Reactions to the use of such technologies can already be seen. In November, pro-government legislators in Hong Kong have suggested enacting a fake news bill [1], similar to that of Singapore's Protection from Online 
Falsehoods and Manipulation bill [56]. In Mainland China, those who are against the protests have changed their tactics on how to spread disinformation online. For example, after platforms limited bots and disinformation accounts from its services, Chinese users have migrated to PornHub to praise HKPF and condemn anti-ELAB protesters [47]. Globally, the protesters in Catalonia have adopted some of the anti-ELAB protesters' techniques and learnt from their downfalls. This includes the creation of Tsunami Democratic, a secure communications app that is not available on any application store and can only be accessed via a QR code from someone who is already a member of the network [13].

Beyond the considerations of this paper, an assessment of how online discourse has changed as monumental events occur could better explain the anti-ELAB movement, particularly where the limitations placed on technology have furthered offline outbreaks of conflict between Hong Kong protesters and authorities. Outside of Hong Kong, understanding how the anti-ELAB protests are understood and defined behind the Great Firewall of China compared to Hong Kong's still relatively free internet can help not only preserve the city's rights and freedoms, but also foster better relationships with those across the border. A comparison on how technology has been used in more recent protests across the globe could also help illuminate how innovations and development in such technologies have purposely or inadvertently changed our socio-political discourse with regards to civil disobedience.

\section{Conclusion}

The anti-ELAB protests did not happen because of technology, but because of the accumulation of socio-political frustrations that the Hong Kong people could not hold the unelected Government accountable for. However, by embedding technology into civil disobedience and including it as part of the anti-ELAB discourse, the movement can maintain its momentum through the demonstration of collective support and participation. Although the protests in Hong Kong continue at the time of writing with no clear end in sight, the use and misuse of technology has already prompted technology companies to change their policies. Demonstrations that began solely from protesting FOMLA have grown to represent the greater fight towards protecting the livelihoods of Hong Kong people as enshrined under the HKBL. In enabling civil disobedience by using technology, anti-ELAB protesters have changed the information discourse in both democratic societies and authoritarian regimes, prompting new questions regarding how digital tools can be used to protect our increasingly intertwined online and offline identities.

\section{References}

[1] Legislative Council Agenda. Internet messages which are fake and jeopardize public safety. Legislative Council. Nov. 5, 2019. URL: https://www.legco.gov.hk/yr19-20/english/ counmtg/agenda / cm20191106. htm \# q 4 (visited on 11/15/2019).

[2] Apple. Apple email to team on HKmap.live. Apple. Oct. 10, 2019. URL: https:// pastebin.com/dFyftCuZ (visited on 11/12/2019).
[3] Adolfo Arranz. The Evolution of Hong Kong's Protesters. South China Morning Post. Sept. 10, 2019. URL: https: //multimedia.scmp.com/infographics/news/hong-kong/ article /3026495/ evolution - of-hong-kong-protesters / index.html (visited on 11/12/2019).

[4] Hong Kong Journalists Association. Joint Statement: Media Organisations oppose fugitives transfer bill. Hong Kong Journalists Association. Apr. 3, 2019. URL: https://www. hkja.org. hk/en/statements / joint - statement - media organisations-oppose-fugitives-transfer-bill/ (visited on 11/12/2019)

[5] Cable. Worldwide broadband speed league 2019. Cable. Nov. 12, 2019. uRL: https://www.cable.co.uk/broadband/ speed/worldwide-speed-league/ (visited on 11/12/2019).

[6] John M. Carroll. A Concise History of Hong Kongs. Lanham, Maryland: Rowman \& Littlefield, 2007. ISBN: 9780190918316.

[7] Holmes Chan. Hong Kong court grants temporary injunction against inciting violence via messaging app Telegram and LIHKG forum. Hong Kong Free Press. Oct. 31, 2019. URL: https://www.hongkongfp.com/2019/10/31/hong-kongcourt-grants-temporary-injunction-inciting-violencevia-messaging-app-telegram-lihkg-forum/ (visited on 11/12/2019).

[8] Holmes Chan. Hong Kong extradition bill to bypass legislative committee scrutiny, as gov't fast-tracks controversial law. Hong Kong Free Press. May 20, 2019. URL: https: / / www . hongkongfp . com / 2019 / 05 / 20 / just - hong kong - extradition - bill - bypass - legislative - committee scrutiny-govt-fast-tracks-controversial-law/ (visited on 11/12/2019).

[9] Kris Cheng. Crowdfunding campaign for jailed activist Edward Leung's appeal surpasses HK\$350,000 goal within 15 minutes. Hong Kong Free Press. Oct. 31, 2019. URL: https: //www. hongkongfp.com/2019/10/05/crowdfundingcampaign - jailed - activist - edward - leungs - appeal surpasses-hk350000-goal-within-15-minutes/ (visited on 11/15/2019).

[10] Kris Cheng. Plan for 'Lady Liberty Hong Kong' pro-democracy statue surpasses $H K \$ 200 k$ crowdfunding goal within hours. Hong Kong Free Press. Aug. 31, 2019. URL: https://www. gofundme.com/f/standwithhk-international (visited on 11/15/2019).

[11] Leung Kai Chi. Leung Kai Chi Twitter. Leung Kai Chi. Sept. 28, 2019. URL: https : / / twitter . com / LeungKaiChiHK (visited on 11/15/2019).

[12] Laurel Chor. Laurel Chor. Laurel Chor. July 24, 2019. URL: https : / / twitter . com / laurelchor / status / 1153950646480957441?s=20 (visited on 11/15/2019).

[13] Laurie Clark. Catalonia has created a new kind of online activism. Everyone should pay attention. Wired. Oct. 19, 2019. URL: https://www.wired.co.uk/article/barcelonia-riotscatalonia-protests-news (visited on 11/15/2019).

[14] Office of the Communications Authority. Key Communications Statistics. The Government of the Hong Kong Special Administrative Region. URL: https://www.info.gov. 
hk/gia/general/201903/26/P2019032600708.htm (visited on $11 / 12 / 2019)$.

[15] Office of the Communications Authority. Key Communications Statistics. The Government of the Hong Kong Special Administrative Region. Nov. 12, 2019. URL: https: //www.ofca.gov.hk/en/data_statistics/data_statistics/ key_stat/index.html (visited on 11/12/2019).

[16] British Broadcasting Corporation. Hong Kong formally scraps extradition bill that sparked protests. British Broadcasting Corporation. Oct. 23, 2019. URL: https://www. bbc.co.uk/news/world-asia-china-50150853 (visited on 11/15/2019).

[17] British Broadcasting Corporation. Hong Kong leader Carrie Lam to withdraw extradition bill. British Broadcasting Corporation. Sept. 4, 2019. uRL: https://www.bbc.co.uk/ news/world-asia-china-49575381 (visited on 11/15/2019).

[18] Hong Kong Trade Development Council. Innovation and Technology Industry in Hong Kong. Hong Kong Trade Development Council. Aug. 21, 2019. URL: http:// hongkong - economy - research . hktdc. com / business - news / article / Hong - Kong - Industry - Profiles / Innovation and - Technology - Industry - in - Hong - Kong/hkip / en / 1/1X000000/1X09U6YK.htm (visited on 11/12/2019).

[19] Jennifer Creery. Over a million attend Hong Kong demo against controversial extradition law, organisers say. Hong Kong Free Press. June 9, 2019. URL: https : / / www . hongkongfp . com / 2019 / 06 / 09 / just - no - china extradition - tens - thousands - hong - kong - protest controversial-new-law/ (visited on 11/12/2019).

[20] Antony Dapiran. Hong Kong's identity as a city of rights and freedom is under threat - so we protest. The Guardian. June 12, 2019. URL: https: / / www . theguardian.com/ commentisfree/2019/jun/12/hong-kongs-identity-asa-city-of-rights-and-freedom-is-under-threat-so-weprotest (visited on 11/12/2019).

[21] Pavel Durow. Pavel Durow DDoS Telegram. Pavel Durow. June 12, 2019. URL: https://twitter.com/durov/status/ 1138942773430804480 (visited on 11/15/2019).

[22] Blizzard Entertainment. Hearthstone Grandmasters AsiaPacific Ruling. Blizzard Entertainment. Oct. 8, 2019. URL: https://playhearthstone.com/en-us/blog/23179289 (visited on 11/12/2019).

[23] Hong Kong Police Force. Police use of term 'riot' to describe protests. Hong Kong Police Force. June 13, 2019. URL: https : / / twitter . com / hkpoliceforce / status / 1139199369071083520 (visited on 11/15/2019).

[24] LIHKG Forum. LIHKG Forum. LIHKG Forum. June 9, 2019. URL: https://lihkg.com (visited on 11/12/2019).

[25] Keyboard Frontline. Protesters' Rights Handbook Mobile Frontline. Keyboard Frontline. Sept. 20, 2014. URL: https : / / drive google . com / file / d / 0B4W7 FlIxRL4Q01jcFh0X3VjVFk/view (visited on 11/12/2019).

[26] Nathaniel Gleicher. Removing Coordinated Inauthentic Behavior From China. Facebook Newsroom. Aug. 19, 2019. URL: https://about.fb.com/news/2019/08/removing-cibchina/ (visited on 11/12/2019).
[27] Goofrider. Goofrider Twitter. Goofrider. Sept. 27, 2019. URL: https : / / twitter . com / goofrider / status / 1166267775267950592? s=20 (visited on 11/15/2019).

[28] James Griffiths. The Great Firewall of China: How to build an control an alternative version of the internet. London: Zed Books, 2019. ISBN: 9781786995353.

[29] The Guardian. Hong Kong bans publication of police personal details, including photos. The Guardian. Oct. 26, 2019. URL: https://www. theguardian.com/world/2019/oct/26/ hong - kong - bans - publication - of - police - personal details-including-photos (visited on 11/12/2019).

[30] Tim Hardwick. Apple Bans App That Allowed Hong Kong Protestors to Track Police Movements [Updated x2]. Mac Rumors. Oct. 3, 2019. URL: https://www.macrumors.com/ 2019/10/03 / apple - bans - app - used - by - hong - kongprotestors/ (visited on 11/12/2019).

[31] HKmap.live. HKmap.live disputes Apple claims. HKmap.live. Oct. 10, 2019. URL: https : / / twitter . com/hkmaplive/status/1182154372563836928 (visited on 11/12/2019).

[32] Legislative Council of the Hong Kong Special Administrative Region of the People's Republic of China. How Laws are Made. Legislative Council of the Hong Kong Special Administrative Region of the People's Republic of China. Dec. 22, 2017. URL: https://www.legco.gov.hk/ education/files/english/Factsheet/Factsheet7. pdf (visited on 11/12/2019).

[33] Legislative Council of the Hong Kong Special Administrative Region of the People's Republic of China. LegCo Today. Legislative Council of the Hong Kong Special Administrative Region of the People's Republic of China. Nov. 12, 2019. URL: https://www.legco.gov.hk/general/ english/intro/about_lc.htm (visited on 11/12/2019).

[34] The Government of the Hong Kong Special Administrative Region. Government response to procession. The Government of the Hong Kong Special Administrative Region. June 9, 2019. URL: https://www.info.gov.hk/gia/ general $/ 201906 / 09 /$ P2019060900587. htm ? fontSize $=1$ (visited on 11/12/2019).

[35] Mary Hui. Hong Kong's protesters put AirDrop to ingenious use to breach China's Firewall. Quartz. July 8, 2019. URL: https : / / qz . com / 1660460 / hong - kong - protesters use - airdrop - to - breach - chinas - firewall/ (visited on 11/12/2019).

[36] Mary Hui. The Hong Kong protests are the most live-streamed protests ever. Quartz. Nov. 11, 2019. URL: https://qz.com/ $1737197 /$ hong-kong-protests-are-most-live-streamedever/ (visited on 11/12/2019).

[37] Mary Hui. Why Hong Kong's protesters were afraid to use their metro cards. Quartz. June 13, 2019. URL: https://qz.com/ 1642441/ extradition-law-why-hong-kong-protesters didnt-use-own-metro-cards/ (visited on 11/12/2019).

[38] Mary Hui and Isabella Steger. The problem with calling Hong Kong's protests a riot goes back to a colonial-era law. Quartz. June 16, 2019. URL: https:// qz.com/1645270/ hong-kong-extradition-protesters-we-are-not-rioters/ (visited on 11/12/2019). 
[39] Shane Huntley. Maintaining the Integrity of Our Platforms. Google. Aug. 22, 2019. URL: https : / / blog . google / outreach - initiatives / public - policy / maintaining integrity-our-platforms/ (visited on 11/12/2019).

[40] Ryan Ho Kilpatrick. Nord VPN most downloaded application in Hong Kong. Ryan Ho Kilpatrick. Oct. 7, 2019. URL: https : / / twitter . com / rhokilpatrick / status / 1181221155807481856 (visited on 11/12/2019).

[41] Freedom Hong Kong and R Referendum. Hong Kong Add Oil. GoFundMe. Aug. 11, 2019. UrL: https : / / www . hongkongfp . com / 2019 / 08 / 31 / plan - lady - liberty hong - kong - pro - democracy - statue - surpasses hk200k-crowdfunding-goal - within-hours/ (visited on 11/15/2019).

[42] Radio Television Hong Kong. Court limits scope of police 'doxxing' order. Radio Television Hong Kong. Oct. 29, 2019. URL: https://news.rthk.hk/rthk/en/component/ $\mathrm{k} 2 / 1488720-20191029$. htm archive_date $=2019-10-29$ (visited on 11/12/2019).

[43] Radio Television Hong Kong. Media granted exemption to police doxxing injunction. Radio Television Hong Kong. Nov. 8, 2019. URL: https : / / news . rthk. hk/rthk/ en / component $/ \mathrm{k} 2 / 1490769-20191108 . \mathrm{htm}$ ? archive_date $=$ 2019-11-08 (visited on 11/12/2019).

[44] Lana Lam. 50,000 CCTV cameras in Hong Kong's skies causing 'intrusion' into private lives. South China Morning Post. Mar. 16, 2014. URL: https : / / www . scmp.com / news / hong-kong/article/1449669/cctv-cameras - run - tens thousands-across-hong-kong (visited on 11/12/2019).

[45] Christy Leung. Hong Kong police say nearly 360 protesters, most younger than 25, could face arrest for clashes after extradition protest march. South China Morning Post. June 10, 2019. URL: https://www.scmp.com/news/hong-kong/ law-and-crime/article/3013910/hong-kong-police-saynearly-360-protesters-most (visited on 11/12/2019).

[46] Linda Lew. Hong Kong protests and 'fake news': in the psychological war for hearts and minds, disinformation becomes a weapon used by both sides. South China Morning Post. Oct. 14, 2019. URL: https://www.scmp.com/news/hongkong/ society / article/ 3032734 / fake - news - and - hong kong - protests - psychological - war - hearts (visited on $11 / 15 / 2019)$

[47] Jane Li. China's messaging against the Hong Kong protests has found a new outlet: PornHub. Quartz. Nov. 13, 2019. URL: https : / qz . com/1747617 / chinese - users - go - to pornhub-to-spread-hong-kong-propaganda/ (visited on 11/15/2019)

[48] Jeff Li. Hong Kong-China extradition plans explained. British Broadcasting Corporation. Aug. 22, 2019. URL: https:// www.bbc.co.uk/news/world-asia-china-47810723 (visited on 11/12/2019).

[49] Taylor Lorenz. When Grown-Ups Get Caught in Teens' AirDrop Crossfire. The Atlantic. June 5, 2019. URL: https:// www . theatlantic.com / technology / archive / 2019/06/ why-teens-try-airdrop-you-memes-concerts/591064/ (visited on 11/12/2019).
[50] Shibani Mahtani. Masks, cash and apps: How Hong Kong's protesters find ways to outwit the surveillance state. Washington Post. June 15, 2019. URL: https : / / www . washingtonpost.com/world/asia_pacific/masks - cash and-apps-how-hong-kongs-protesters-find-ways-tooutwit-the-surveillance-state/2019/06/15/8229169c8ea0 - 11e9-b6f4-033356502dce_story.html (visited on 11/12/2019).

[51] Simone McCarthy. First Hongkongers collect new smart ID cards with replacement roll-out to start soon. South China Morning Post. Oct. 10, 2018. uRL: https : / / www . scmp . com / news / hong - kong / article / 2177310 / first hongkongers-collect-new-smart-id-cards-replacementroll-out (visited on 11/12/2019).

[52] ncehk2019. Livestreams of anti-ELAB protests. ncehk2019. June 12, 2019. URL: https:// ncehk2019. github.io/ncelive/?visibleCount=9 (visited on 11/15/2019).

[53] Stand News. Hong Kong protesters hold 'first civil press conference'. The Guardian. Aug. 6, 2019. URL: https://www. theguardian.com/global/video/2019/aug/06/hong-kongprotesters-hold-first-civil-press-conference-video (visited on 11/15/2019).

[54] Stand News. Hong Kong: anti-surveillance protesters tear down 'smart' lamp-post - video. The Guardian. Aug. 26, 2019. URL: https : / / www . theguardian . com / world / video / 2019 / aug / 26 / hong - kong - anti - surveillance protesters-tear-down-smart-lamp-post-video (visited on 11/12/2019).

[55] Alex Palmer. The Case of Hong Kong's Missing Booksellers. New York Times. Apr. 3, 2018. URL: https : / / www . nytimes.com/2018/04/03/magazine/the-case-of-hongkongs-missing-booksellers.html (visited on 11/12/2019).

[56] Parliament of Singapore. "Protection from Online Falsehoods and Manipulation". In: Parliament of Singapore 10 (Apr. 1, 2019), pp. 1-81. URL: https://www.parliament. gov.sg/docs/default-source/default-document-library/ protection-from-online-falsehoods-and-manipulationbill10-2019.pdf.

[57] Alex Pentland. "The Data-Driven Society". In: Scientific American 309 (Oct. 2013), pp. 78-83. URL: https://www. scientificamerican . com / article / how - big - data - can transform-society-for-the-better/.

[58] Pinboard. Pinboard disputes Apple claims on HKmap.live. Pinboard. Oct. 10, 2019. URL: https : / / twitter. com / Pinboard / status / 1182348757360234497 (visited on 11/12/2019).

[59] South China Morning Post. 'Nearly 2 million' people take to streets, forcing public apology from Hong Kong leader Carrie Lam as suspension of controversial extradition bill fails to appease protesters. South China Morning Post. June 16, 2019. URL: https://www.scmp.com/news/hong-kong/politics/ article/3014737/nearly-2-million-people-take-streetsforcing-public-apology (visited on 11/15/2019).

[60] South China Morning Post. As it happened: Hong Kong police and extradition protesters renew clashes as tear gas flies. South China Morning Post. June 12, 2019. URL: https: //www.scmp.com/news/hong-kong/politics/article/ 
3014104 / thousands - block - roads - downtown - hong kong-defiant-protest (visited on 11/12/2019).

[61] Counterpoint Research. China Smartphone Market Share: By Quarter. Counterpoint Research. Aug. 28, 2019. URL: https : / / www . counterpointresearch . com / china smartphone-share/ (visited on 11/12/2019).

[62] Twitter Safety. Information operations directed at Hong Kong. Twitter. Aug. 19, 2019. URL: https://blog.twitter. com / en _ us / topics / company / 2019 / information _ operations_directed_at_Hong_Kong. html (visited on 11/12/2019).

[63] Joel Schectman. Exclusive: Messaging app Telegram moves to protect identity of Hong Kong protesters. Reuters. Aug. 31, 2019. URL: https : / / www . reuters . com / article / us hongkong - telegram - exclusive - idUSKCN1VK2NI (visited on 11/12/2019).

[64] The Royal Swedish Academy of Sciences. The Nobel Prize in Physics 2009. Nobel Prize. Oct. 9, 2009. URL: https:// www . nobelprize . org / prizes / physics / 2009 / summary/ (visited on 11/12/2019).

[65] Edward Snowden. Permanent Record. London: Metropolitan Books, 2019. ISBN: 9781529035650.

[66] Internet Society. Challenge against govt's injunction to block free speech online. Internet Society. Nov. 12, 2019. URL: https : / / gogetfunding . com / jrcensorship/ (visited on 11/12/2019).

[67] Internet Society. Internet Society Deeply Concerned about Interim Injunction Ordered by Hong Kong High Court. Internet Society. Nov. 11, 2019. URL: https : / / www . internetsociety . org / news / statements / 2019 / interim injunction-ordered-by-hong-kong-high-court/ (visited on 11/12/2019).

[68] Nick Statt. Apple removes Quartz news app from the Chinese App Store over Hong Kong coverage. The Verge. Oct. 9, 2019. URL: https://www.theverge.com/2019/10/9/20907228/ apple - quartz - app - store - china - removal - hong - kongprotests-censorship (visited on 11/12/2019).

[69] The Government of the Hong Kong Special Administrative Region. "Criminal Matters Ordinance". In: The Government of the Hong Kong Special Administrative Region 525 (Apr. 11, 2019). URL: https://www.hklii.hk/eng/hk/legis/ ord/525/index.html.

[70] The Government of the Hong Kong Special Administrative Region. "Fugitive Offenders Ordinance". In: The Government of the Hong Kong Special Administrative Region 503 (Apr. 25, 2013). URL: https://www.hklii.hk/eng/hk/legis/ ord/503/index.html.

[71] The Government of the Hong Kong Special Administrative Region. "Prohibition on Face Covering Regulation". In: The Government of the Hong Kong Special Administrative Region 241K (Oct. 5, 2019). URL: https://www.elegislation. gov.hk/hk/cap241K.

[72] The Government of the Hong Kong Special Administrative Region. "Public Order Ordinance". In: The Government of the Hong Kong Special Administrative Region 245 (Nov. 17, 1967). URL: https://www.elegislation.gov.hk/ hk/cap245.
[73] The Government of the Hong Kong Special Administrative Region. "The Basic Law of the Hong Kong Special Administrative Region of the People's Republic of China". In: The Government of the Hong Kong Special Administrative Region (July 1, 1997), pp. 1-156. URL: https:// www.basiclaw.gov.hk/en/basiclawtext/images/basiclaw_ full_text_en.pdf.

[74] Elson Tong. Reviving Article 23 (Part I): The rise and fall of Hong Kong's 2003 national security bill. Hong Kong Free Press. Feb. 17, 2018. URL: https://www.hongkongfp.com/ 2018 / 02 / 17 / reviving - article - 23 - part - i - rise - fall hong - kongs - 2003 - national - security - bill/ (visited on 11/12/2019).

[75] Daniel Trottier and Christian Fuchs, eds. Social Media, Politics and the State. Abingdon-on-Thames: Routledge, 2015. ISBN: 9781138798243.

[76] Zeynep Tufekci. Twitter and Tear Gas. New Haven, Connecticut: Yale University Press, 2017. ISBN: 9780300234176.

[77] uwu. uwu Twitter. uwui. Sept. 24, 2019. URL: https : / / twitter . com / uwu _ uwu _ mo / status / 1176630543049515009 (visited on 11/15/2019).

[78] Danny Vincent. Danny Vincent. British Broadcasting Corporation. Aug. 9, 2019. URL: https://www.bbc.co.uk/ news/technology-49280726 (visited on 11/15/2019).

[79] Human Rights Watch. China: Release Human Rights Lawyers. Human Rights Watch. Feb. 15, 2018. URL: https: //www.hrw.org/news/2018/02/15/china-release-humanrights-lawyers (visited on 11/12/2019).

[80] Human Rights Watch. Hong Kong: Face Mask Ban Violates Assembly Rights. Human Rights Watch. Oct. 4, 2019. URL: https://www.hrw.org/news/2019/10/04/hong-kongface - mask - ban - violates - assembly - rights (visited on 11/12/2019).

[81] Nils B. Weidmann and Espen Geelmuyden Rød. The Internet and Political Protest in Autocracies. Oxford: Oxford University Press, 2019. ISBN: 9780190918316.

[82] Brian Wong. Injunction to shield Hong Kong voter register from public to prevent doxxing to remain through district council elections - as police group pleas to make it permanent. South China Morning Post. Oct. 23, 2019. URL: https://www. scmp.com/news / hong-kong/law - and-crime / article / 3034250/injunction-shield-hong-kong-voter-registrypublic (visited on 11/12/2019).

[83] Candice Wong. Legal sector warns fugitives plan must be dropped. Radio Television Hong Kong. Apr. 8, 2019. URL: https://news.rthk.hk/rthk/en/component/k2/145180820190408.htm (visited on 11/12/2019).

[84] Sui-lin Wong and Ravi Mattu. Hong Kong protesters try to woo Chinese tourists to their cause. Financial Times. July 7, 2019. URL: https://www.ft.com/content/e4f93f2a-a09f11e9-a282-2df48f366f7d (visited on 11/12/2019).

[85] Tsui-kai Wong. Hong Kong protests: What are the five demands? What do protesters want? Young Post. Aug. 20, 2019. URL: https://yp.scmp.com/hongkongprotests5demands (visited on 11/12/2019). 
[86] Iris Yang. More than gamers: Diving deeper into one of Hong Kong's most engaged audiences. Think with Google. Nov. 1, 2019. URL: https://www.thinkwithgoogle.com/intl/en$\mathrm{apac} /$ trends - and-insights/more-than-gamers-divingdeeper - into - one - of - hong - kongs - most - engaged audiences/ (visited on 11/12/2019).

[87] William Yang. Hong Kong 'suspends work' on controversial extradition bill. Deutsche Welle. June 15, 2019. URL: https: //www.dw.com/en/hong-kong-suspends-work-oncontroversial - extradition-bill / a - 49216048 (visited on 11/15/2019).

[88] Cannix Yau. Hong Kong's extradition proposal could undermine rule of law and competitiveness, says Tara Joseph of the American Chamber of Commerce. South China Morning Post. May 19, 2019. URL: https://www.scmp.com/ news/hong-kong/politics/article/3010798/hong-kongsextradition-proposal - could - undermine - rule-law (visited on $11 / 12 / 2019)$. 